\title{
Drudgery Reduction through Ergonomic Evaluation of Women Farm Workers using Local Sickle and Serrated Sickle During Harvesting in Wheat Crop of Udaipur District
}

\author{
M. Anusha* and A. K. Mehta \\ Department of Farm Machinery and Power Engineering, College of Technology and \\ Engineering, Maharana Pratap University of Agriculture \& Technology, Udaipur-313001 \\ (Rajasthan) \\ *Corresponding author
}

\section{A B S T R A C T}

\section{Keywords}

Agricultural activities, Women farm workers, Harvesting, Ergonomic assessment

Article Info

Accepted:

12 December 2020 Available Online: 10 January 2021
Women play a major and crucial role in doing the agricultural operations. The women workers in Udaipur district mostly uses local made sickle for doing harvesting operation. This study was conducted in 2019-20 at instructional Farm, CTAE, Udaipur with ten women farm workers during the manual harvesting operation by using local sickle along with serrated sickle. The main objective of the study was to investigate the most drudgery prone tool and to recommend the proper tool for doing harvesting operation in wheat crop. Use of proper tools not only reduce the drudgery but also improves the operating efficiency along with the comfort, besides improving the productivity of the women farm workers in doing the operation. In view of this, an effort has been made to assess the physical and physiological parameters of women farm workers who are using local sickle along with the serrated sickle for doing harvesting operation in wheat crop. The whole study was conducted on ten female farm workers identified from the population of workers in the age group of 18 to 45 years. During the experiment, the average working heart rate, Energy expenditure rate, Oxygen consumption rate, physiological cost of work of women farm workers using local sickle was 103.65 beats $/ \mathrm{min}, 11.67 \mathrm{~kJ} / \mathrm{min}, 0.57 \mathrm{l} / \mathrm{min}, 18.44$ beats $/ \mathrm{m}^{2}$ and for serrated sickle 111.55 beats $/ \mathrm{min}, 15.62 \mathrm{~kJ} / \mathrm{min}, 0.62 \mathrm{l} / \mathrm{min}, 14.96$ beats $/ \mathrm{m}^{2}$.The overall discomfort rate at the end of the work for local and serrated sickle was 7.6 and 6.8 . The reduction of drudgery by using serrated sickle over local sickle was found to be $18.87 \%$. The rating of perceived exertion given by the female farm workers at the end of the work was found to be less for serrated sickle i.e., 3.6 and for local sickle, it was 4.2.

\section{Introduction}

Female agricultural workers in India play dominant role in agriculture production and productivity. They are involved in various agricultural operations and their participation varies with region, crops, commodities and socio-economic studies.Drudgery is mostly perceived as physical and nervousness, exhaustion, tedium and sufferings experienced while doing a particular task. It is evident, that if proper drudgery reducing 
farmstead implements are made available to the rural agricultural farm women, these would contribute to reduction in drudgery, increase ability, throughput and subsequently the greater workload thereby enhanced efficiency. Harvesting operation in wheat crop is mostly done by the female farm workers manually under heat stress and also very laborious operation. These agricultural operations performed by women involve a lot of physical strain, which create serious health problemsin the long run, besides developing some Musculo-skeletal problems which mainly occurs due to the inconvenient work postures (Chauhan, 1999). It is also concluded that combination of standing and bending postures were generally used by most of the farm women for performing cutting operations (Bora and kalita, 2002).

Harvesting operation in wheat crop is arduous and extremely demanding the women farm workers especially for those farm units less than 2 hectares and experiences drudgery while doing the operation. Daily with eight hours of labour, starting from morning to evening, besides women farm workers usually adopts squatting, bending position for extended duration. It is also revealed that the foremost of the women experienced severe to moderate severe pain in neck due to the constant muscle contraction and also suffered from pain in upper leg, lower back and calf muscles, ankle and wrist who were involved in cutting (Anon, 2001-02)

Research studies considering women's role especially that of rural women in agriculture activities are inadequate. In terms of research very few studies regarding women participation in agriculture activities and extremely limited studies are available to ease the drudgery perceived and physiological cost during the farm operations in Udaipur district. Keeping in sight the dearth of information alarming women participation in agriculture activities, the study in hand is instigated to fill these gaps.

\section{Justification of the Research Study}

Research studies investigating the Ergonomical studies on agriculture workers particularly about rural women workers in agriculture activities are scarce. In terms of research very few studies pertaining to ergonomics in agriculture activity i.e., during harvesting operation in wheat crop have been carried out in India, in particular, Udaipur district.

The objectives of the study include to assessment of physiological parameters, heart rate (HR), cardiac cost, oxygen consumption rate (OCR) and Energy expenditure rate (EER) during harvesting operation in wheat crop with local sickle and ergonomically improved serrated sickle. Assessment of overall discomfort rating (ODR) before and after the operation. Assessment of Rating of perceived exertion after the operation. Assessment of Musculo-skeletal problems after the operation. Problems faced by the women farm workers with local sickle and comparison of local sickle with serrated sickle.

\section{Materials and Methods}

Physiological and physical workload was calculated during the harvesting operation of wheat crop which was performed in the month of April, 2019-20 at CTAE Instructional farm, Udaipur. The study was conducted on ten female farm workers selected from the representative population of workers between $5^{\text {th }}$ and $95^{\text {th }}$ percentile of the anthropometric criteria. During the study period all the operations were performed by these ten female farm workers only. Selected subjects had agriculture as their main source of occupation. 
All the subjects selected did not have the habits of chewing tobacco and taking any type of liquor. Subjects were between 18-45 years of age. Subjects were free from any chronological disease, physical disorder and were medically fit. In morning, the uniform time of $6 \mathrm{~h}$ for weeding operation was given in between $9 \mathrm{AM}$ to $1 \mathrm{PM}$ and in evening from 2 $\mathrm{PM}$ to 5 PM.

All the female farm workers were allowed to take rest for 15 minutes before performing the task and asked to perform the harvesting operation continuously for 30 minutes and then allowed to take rest for 15 minutes. The same procedure was followed for both sickle and ergonomically developed serrated sickle by following proper work-rest cycle.

For assessment of effect of physiological and physical work load on the performance of female farm workers, two different tools namely local sickle and serrated sickle in wheat crop during harvesting operation were taken as independent parameters.

Six dependent parameters includes three physiological workloads namely heart rate (HR), oxygen consumption rate (OCR) and energy expenditure rate (EER) and three physical workloads namely, Overall discomfort rate (ODR), Rate of perceived exertion and Musculo-skeletal disorders were selected for this study.

\section{Instrumentation}

During the experiment, the measuring tape and weighing scale were used to measure the physical characteristics like height and weight. Instrumentation used to conduct the experiments for measurement of physiological and physical workload is described below.

\section{Physiological workload}

\section{Computerized ambulatory metabolic measurement system}

The computerized ambulatory metabolic measurement system measures the oxygen consumption at every breath that's why it is known for breath by breath measurement and is more accurate than mixing chamber measurement. Heart rate (resting HR, working HR) and oxygen consumption rate and energy expenditure rate (EER) were directly measured by using $\mathrm{K} 4 \mathrm{~b}^{2}$ make by Cosmed (Italy). Varghese et al., 1994 given the following formula. Increase in Heart rate $(\Delta \mathrm{HR})$, cardiac cost and output was calculated by using the following given formula.

1. Increase in Heat rate, $\Delta \mathrm{HR}$ (beats $/ \mathrm{min}$ ) = Average working heart rate - Average resting heart rate

2. Output $(\mathrm{m} 2 / \mathrm{h})=$ area covered $\mathrm{x}$ duration / average time

3. Cardiac cost/physiological cost of worker per unit of output (beats/ $\mathrm{m} 2$ area covered) = $\Delta$ HR x duration / output.

\section{Physical workload}

\section{Overall Discomfort Rating (ODR)}

Overall discomfort rating (ODR) had been defined by using a 10-point psycho-physical rating scale developed by Borg in 1990. A scale of $70 \mathrm{~cm}$ length was fabricated having 0 to 10 digits marks on it equidistantly as shown below. A flexible pointer to indicate the rating was provided. The subject was asked to report her discomfort level on the scale before start of work. She was again asked to report the discomfort level at the end of work. The difference in the score of before and after the work was the real discomfort score. 


\section{Rating of perceived exertion}

Rating of Perceived Exertion was measured at 5-point scale developed by Varghese et al., (1994) very light -1 , light- 2 , moderately heavy-3, heavy- 4 , very heavy- 5

\section{Body part discomfort score (BPDS)}

The Musculo-skeletal problems during the activity were identified with the help of body map (Corlett and Bishop, 1976) known as Body part discomfort score (BPDS), which indicates different body parts (Figure-2) viz; upper body parts (eye, neck, shoulder joint, upper arm, elbows, wrist/hands) and lower body parts (lower arm, low back, upper leg/ thigh, knees, calf muscles, ankles, feet).

\section{Results and Discussion}

The performance of Local sickle and serrated sickle was compared. The physical dimensions of studied sickles were compared against standards given by BIS (1967). The details are indicated clearly in Table 1. and Fig 2. shows the sickles used in this study for harvesting operation in wheat crop.

To reduce the drudgery in the harvesting operation through ergonomic point of view, ten female farm workers were selected in the age group of 18 to 45 years were selected at random and average age of the respondents engaged in wheat harvesting operation was counted as 33.30 years measuring body height of $149 \mathrm{~cm}$, weight as $45.4 \mathrm{~kg}$ and Body mass index (BMI) as 20.58 respectively. The Physical characteristics of ten selected female farm workers are indicated in Table 2.

Physiological workload during the harvesting operation of wheat crop was determined on the basis of various parameters like average heart rate during work and rest, oxygen consumption rate energy expenditure rate and physiological cost of work while performing the activity.

Physiological workload from the observation given in Table 3 , clearly indicated the area covered by the local sickle was $72.68 \mathrm{~m}^{2} / \mathrm{h}$ by local sickle as compared to serrated sickle which was $90.18 \mathrm{~m}^{2} / \mathrm{h}$. Alka et al., (2014) also stated that the serrated sickle resulted in higher output than local sickle because of the less pushing force required, which was resulted in higher cutting speed and hence resulted in increased output and reduced drudgery by $18.87 \%$. Gite et al., (2000), also stated that the serrated sickle reduces the drudgery by $16.50 \%$ when compared to local sickle.

During harvesting with local sickle, the average $\Delta \mathrm{HR}$ was 22.12 beats/min, Energy Expenditure Rate was $11.67 \mathrm{~kJ} / \mathrm{min}$, Oxygen consumption rate was $0.57 \mathrm{l} / \mathrm{min}$ and physiological cost of work was 18.44 beats $/ \mathrm{m}^{2}$ whereas with serrated sickle, the average $\Delta H R$ was 24.23 beats/min, Energy Expenditure Rate was $15.62 \mathrm{~kJ} / \mathrm{min}$, Oxygen consumption rate was $0.62 \mathrm{1} / \mathrm{min}$ and physiological cost of work was 14.96 beats $/ \mathrm{m}^{2}$. Dilbaghi et al., (2008), Alka et al., (2014) also found the maximum output and reduction in physiological cost of work with serrated sickle.

Fig 3(a), Fig 3(b), shows female farm workers while doing harvesting operation using local sickle and serrated sickle. The overall discomfort rating (ODR) at the beginning of the operation and at the end of the operation using plain sickle was 1.5 and 7.6 and for serrated sickle, 1.5 and 6.8 respectively. The Rating of perceived exertion for local sickle was given as 4.5 and for serrated sickle as 3.4. 
Table.1 Physical dimensions of studied sickles against standards given by BIS (1967)

\begin{tabular}{|c|l|c|c|c|}
\hline sno & \multicolumn{1}{|c|}{ particulars } & $\begin{array}{c}\text { BIS } \\
(\mathbf{1 9 6 7 )}\end{array}$ & Local sickle & Serrated sickle \\
\hline $\mathbf{1 .}$ & Total Weight, $\mathrm{g}$ & & 0.206 & 0.172 \\
\hline $\mathbf{2 .}$ & Base plate for blade of sickle, $\mathrm{mm}$ & $12 \pm 2$ & 8 & 57 \\
\hline $\mathbf{3 .}$ & Maximum width of the blade, $\mathrm{mm}$ & $28 \pm 3$ & 30 & 24 \\
\hline $\mathbf{4 .}$ & Blade thickness, $\mathrm{mm}$ & $4 \pm 0.5$ & 2.59 & 1.69 \\
\hline $\mathbf{5 .}$ & Outer length of blade & - & 172 & 261 \\
\hline $\mathbf{6 .}$ & Blade concavity, $\mathrm{mm}$ & 59 & 62 & 43 \\
\hline $\mathbf{7 .}$ & Sickle length, $\mathrm{mm}$ & 125 & 285 & 135 \\
\hline $\mathbf{8 .}$ & Maximum length of handle, $\mathrm{mm}$ & & 105 & 100 \\
\hline $\mathbf{9 .}$ & Effective handle length, $\mathrm{mm}$ & & 105 & 30 \\
\hline $\mathbf{1 0}$ & Max diameter of handle, $\mathrm{mm}$ & $224 \pm 3$ & 40 & 238 \\
\hline $\mathbf{1 1}$ & Size of sickle, $\mathrm{mm}$ & & 155 & \\
\hline
\end{tabular}

Table.2 Physical characteristics of selected female farm workers with number of subjects $(\mathrm{N}=10)$

\begin{tabular}{|l|l|c|}
\hline SNo & $\begin{array}{l}\text { Physical characteristics of } \\
\text { female farm workers }\end{array}$ & $\begin{array}{c}\text { Mean } \pm \text { Standard } \\
\text { deviation }\end{array}$ \\
\hline 1. & Age (years) & $33.30 \pm 9.25$ \\
\hline 2. & Height $(\mathrm{cm})$ & $149 \pm 7.18$ \\
\hline 3. & Weight $(\mathrm{Kg})$ & $45.4 \pm 5.72$ \\
\hline 4. & Body mass index $(\mathrm{BMI})$ & $20.58 \pm 2.03$ \\
\hline
\end{tabular}

Table.3 Evaluation of performance data of different parameters of the farm women while performing harvesting operation $(\mathrm{N}=10)$

\begin{tabular}{|c|c|c|}
\hline Particulars & \multicolumn{2}{|c|}{ Mean \pm Standard deviation } \\
\hline Type of tool used & Local plain sickle & Serrated sickle \\
\hline Time of operation per subject (hours) & 1 & 1 \\
\hline Average working heart rate (beats/min) & $103.65 \pm 3.62$ & $111.55 \pm 3.96$ \\
\hline Average resting heart rate (beats/min) & $81.53 \pm 2.38$ & $87.32 \pm 2.07$ \\
\hline Average recovery heart rate (beats/min) & $90.12 \pm 4.04$ & $96.7 \pm 1.62$ \\
\hline$\Delta H R$ (working HR - resting HR) (beats/min) & $22.12 \pm 3.81$ & $24.23 \pm 4.89$ \\
\hline Area covered/output $\left(\mathrm{m}^{2} / \mathrm{h}\right)$ & $72.68 \pm 4.8$ & $90.18 \pm 5.84$ \\
\hline Energy Expenditure Rate (kJ/min) & $11.67 \pm 0.98$ & $15.62 \pm 1.54$ \\
\hline Oxygen consumption rate, $\mathrm{OCR}, \mathrm{l} / \mathrm{min}$ & $0.57 \pm 0.05$ & $0.62 \pm 0.03$ \\
\hline Physiological cost of work (beats/m²) & $18.44 \pm 4.03$ & $14.96 \pm 3.61$ \\
\hline Reduction in drudgery $(\%)$ & - & 18.87 \\
\hline $\begin{array}{l}\text { Overall discomfort rating (ODR) at the starting } \\
\text { of work }\end{array}$ & 1.1 & 1.25 \\
\hline $\begin{array}{l}\text { Overall discomfort rating (ODR) at the end of } \\
\text { the work }\end{array}$ & 6.9 & 5.5 \\
\hline Overall discomfort rating (ODR)(start-end) & 5.8 & 4.3 \\
\hline Rating of perceived exertion (RPE) & 4.2 & 3.6 \\
\hline
\end{tabular}


Table.4 Correlation coefficient computed between different variables and energy expenditure with two different tools $(\mathrm{N}=10)$

\begin{tabular}{|l|c|c|}
\hline Particulars & \multicolumn{2}{|c|}{ Energy expenditure rate (EER) (kJ/s) } \\
\hline Type of tool used & Local plain sickle & Serrated sickle \\
\hline Age (years) & $-0.56^{*}$ & $-0.33^{*}$ \\
\hline Height $(\mathbf{c m})$ & 0.0096 & 0.54 \\
\hline Weight $(\mathbf{k g})$ & 0.04 & 0.25 \\
\hline Average working heart rate (beats/min) & $0.60^{* *}$ & $0.95^{* *}$ \\
\hline Average resting heart rate (beats/min) & $0.19^{* *}$ & $0.21^{* *}$ \\
\hline Average recovery heart rate (beats/min) & $0.42^{* *}$ & $0.75^{* *}$ \\
\hline Oxygen consumption rate, OCR, $\mathbf{( 1 / m i n )}$ & 0.90 & 0.52 \\
\hline AHR (beats/min) & 0.45 & 0.86 \\
\hline Area covered/duration $\left(\mathbf{m}^{\mathbf{2}} / \mathbf{h r}\right)$ & 0.36 & 0.09 \\
\hline Physiological cost of work $\left(\mathbf{b e a t s} / \mathbf{m}^{\mathbf{2}}\right)$ & 0.44 & 0.54 \\
\hline
\end{tabular}

*Significant at $\mathrm{P}=0.05, * *$ Significant at $\mathrm{P}=0.01$

Table.5 Correlation coefficient computed amongst the variables of serrated sickle with number of subjects $(\mathrm{N}=10)$

\begin{tabular}{|c|c|c|c|c|c|c|}
\hline Particulars & $\begin{array}{c}\text { Age } \\
\text { (years) }\end{array}$ & $\begin{array}{c}\text { Weight } \\
\text { (kg) }\end{array}$ & $\begin{array}{c}\text { Average } \\
\text { WHR(bp } \\
\text { m) }\end{array}$ & $\begin{array}{c}\Delta \mathrm{HR} \\
(\mathrm{bpm})\end{array}$ & $\begin{array}{c}\text { Area } \\
\text { covered } / \mathbf{d} \\
\text { uration } \\
\left(\mathbf{m}^{2} / \mathbf{h r}\right)\end{array}$ & $\begin{array}{c}\text { Cardiac } \\
\text { cost } \\
\left(\text { beats } / \mathbf{m}^{2}\right)\end{array}$ \\
\hline Age (years) & 1.00 & & & & & \\
\hline Weight $(\mathbf{k g})$ & 0.04 & 1.00 & & & & \\
\hline Average WHR(bpm) & -0.35 & 0.14 & 1.00 & & & \\
\hline$\Delta \mathrm{HR}$ (beats/min) & 0.57 & $0.20^{* *}$ & $0.91^{*}$ & 1.00 & & \\
\hline Area covered/duration $\left(\mathrm{m}^{2} / \mathrm{hr}\right)$ & 0.17 & -0.05 & 0.01 & -0.05 & 1.00 & \\
\hline Cardiac cost (beats $\left./ \mathrm{m}^{2}\right)$ & -0.0005 & $0.55^{* *}$ & $0.57^{*}$ & $0.38^{* * *}$ & -0.13 & 1.00 \\
\hline
\end{tabular}

$*$ Significant at $\mathrm{P}=0.05, * *$ Significant at $\mathrm{P}=0.01$

Table.6 Problems faced by the women farm workers with local sickle and comparison of local sickle with serrated sickle

\begin{tabular}{|l|l|}
\hline Local sickle & Serrated sickle \\
\hline $\begin{array}{l}\text { Feels heavy with sickle while doing the } \\
\text { operation }\end{array}$ & Feels light in weight \\
\hline $\begin{array}{l}\text { Due to heaviness of handle, more stress } \\
\text { on hand and elbow which leads to pain }\end{array}$ & No heaviness and easy to handle \\
\hline $\begin{array}{l}\text { Sharpening of blade frequently before } \\
\text { doing the operation }\end{array}$ & $\begin{array}{l}\text { No sharpness required due to serrated edge } \\
\text { of blade }\end{array}$ \\
\hline Minimum area is covered per unit time & More area is covered in same time \\
\hline No proper cutting of crop & Proper cutting of crop from the bottom \\
\hline
\end{tabular}


Table.7 Mean scores of The Body part discomfort score (BPDS) of female farm workers during harvesting of wheat crop $(\mathrm{N}=10)$

\begin{tabular}{|c|c|c|}
\hline \multirow{2}{*}{ Subjects } & \multicolumn{2}{|c|}{ Body part discomfort score(BPDS) } \\
\cline { 2 - 3 } & Local sickle & Serrated sickle \\
\hline S1 & 67 & 55 \\
\hline S2 & 50 & 61 \\
\hline S3 & 58 & 52 \\
\hline S4 & 55 & 50 \\
\hline S5 & 55 & 41 \\
\hline S6 & 56 & 49 \\
\hline S7 & 57 & 39 \\
\hline S8 & 56 & 46 \\
\hline S9 & 56 & 51 \\
\hline S10 & 52 & 50 \\
\hline Mean score & 56.2 & 49.4 \\
\hline
\end{tabular}

Fig.1(a) ODR 10-Point Scale

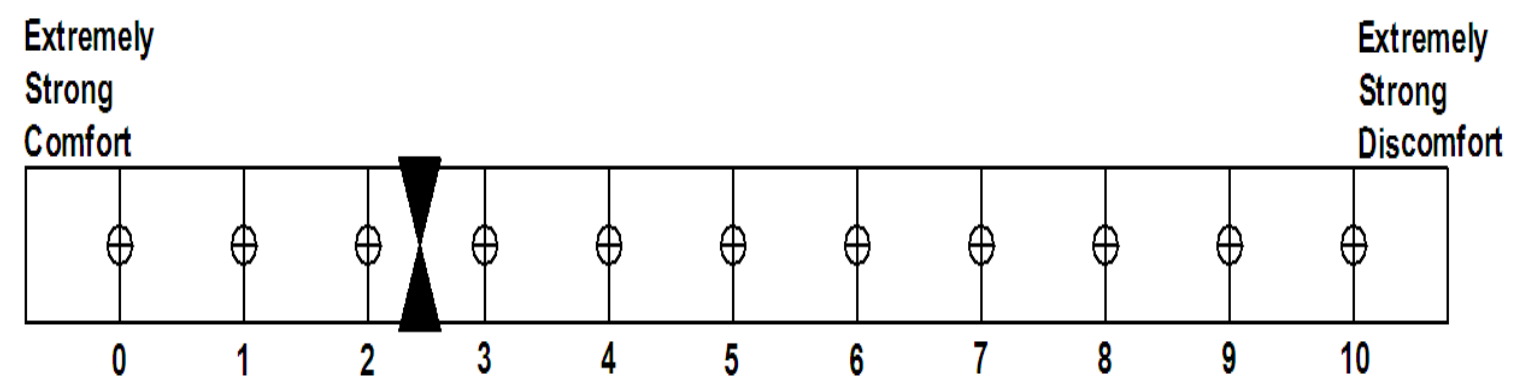

Fig1(b) Body parts for evaluation of body part discomfort score using Corlett and Bishop (1976)

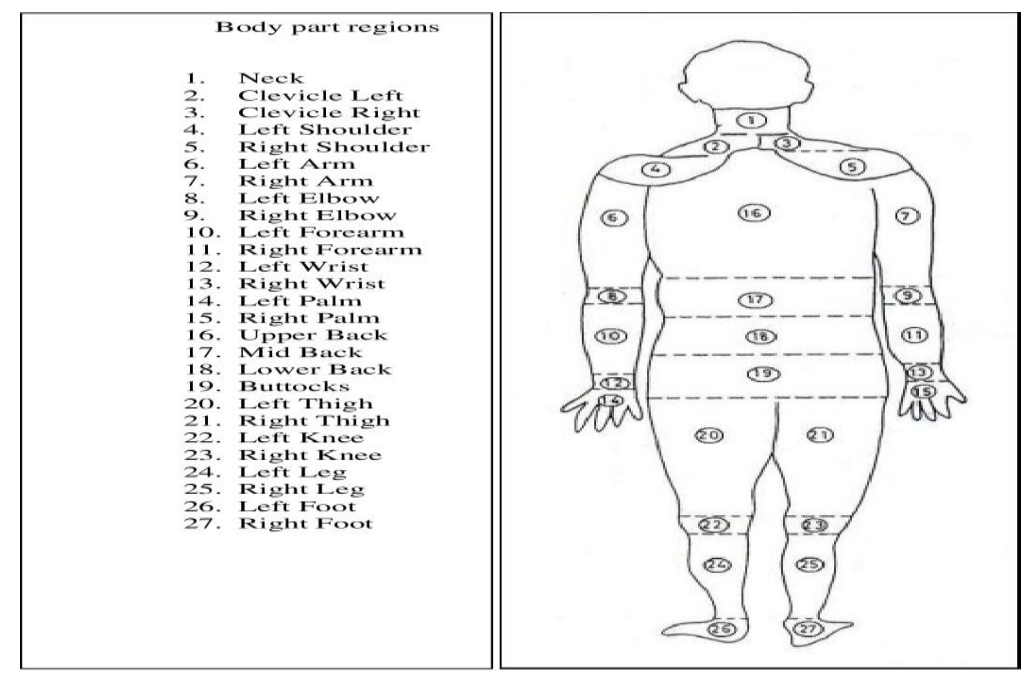


Fig.2
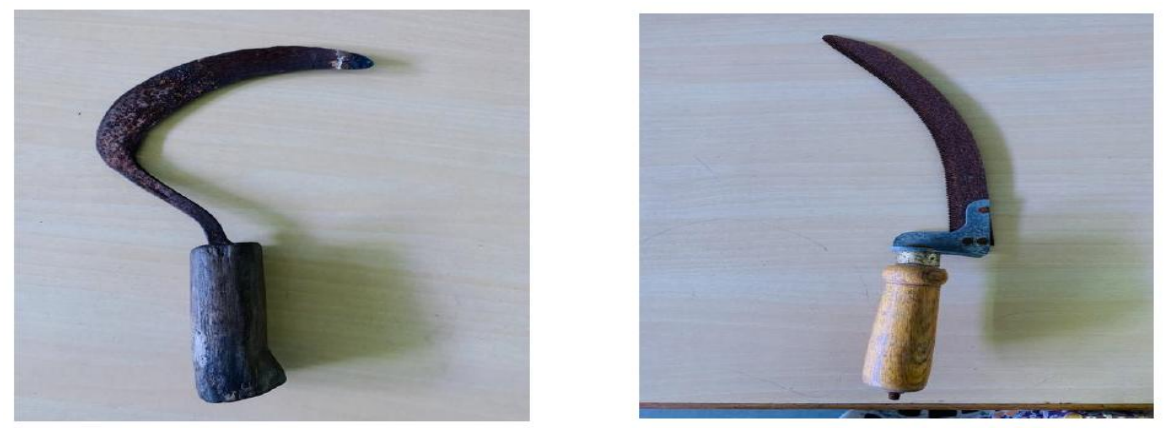

Fig.3
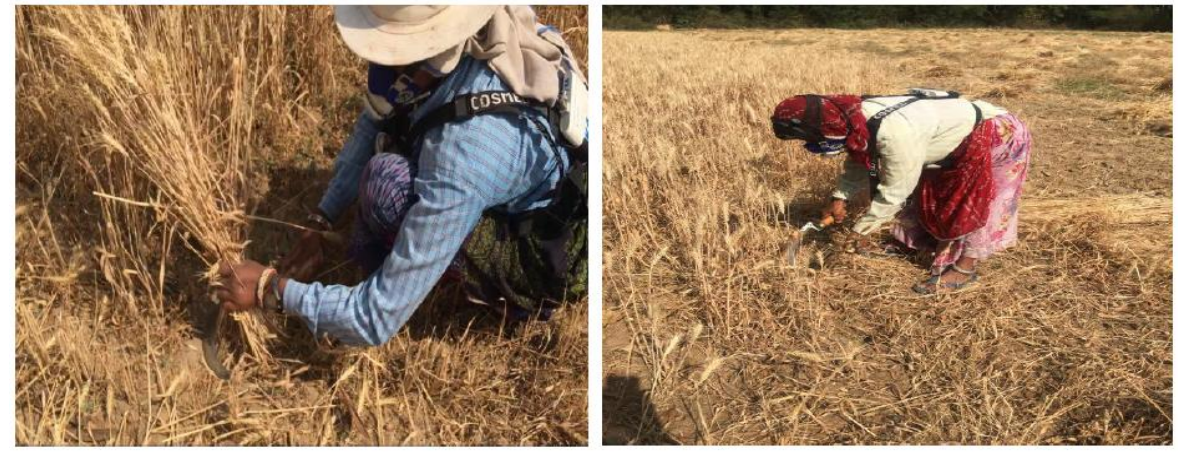

Table 4. shows the correlation coefficient computed between different variables and energy expenditure. It reveals that the age of the respondents showed non significant negative correlation $(r=-0.56, r=-0.33)$ for local sickle and serrated sickle which means that age is not responsible for effecting efficiency of the work. Remaining all the parameters showed positive correlation with energy expenditure rate. Table 5. Shows the correlation coefficient among the variables of the serrated sickle. Singh et al., (2014), has also reported the positive correlation between cardiac cost and average working heart rate during harvesting operation with improved sickle.

Table 6. shows the problem faced by the women farm workers while doing harvesting operation with local sickle and the problems are compared with the solutions with serrated sickle.

\section{Body parts discomfort score(BPDS)}

The subjects were allowed to perform harvesting operation in wheat crop by using sickle and serrated sickle. Evaluation of body part discomfort score (BPDS) was carried out by using Corlett and Bishop (1976) technique. The discomfort in different body parts was identified by the female farm workers by using the body map shown in Fig 1(b).

The values of Body part discomfort score of ten female farm workers are indicated below in table 7. It indicates the BPDS for sickle ranged between 50-67 and for serrated sickle BPDS score was 39-61. The majority of discomfort experienced by female farm workers was more in case of sickle. The Body part discomfort score(BPDS) was less in serrated sickle as compared with the local sickle. 
In conclusions the serrated sickle when compared to local sickle is more women friendly following all the ergonomic considerations for reducing the drudgery of the women farm workers by $18.87 \%$. It also reduces the Musculo-skeletal problems as indicated in mean score using the body map during the harvesting operation and also provides safety and reliability to the farm workers due to lower weight, easy to handle and better construction and it requires no frequent sharpening of the blade sue to its serrated edge which makes the cutting more easier and faster compared to local sickle. This not only reduces the drudgery but also reduces the fatigue, tiredness, exertion when proper work-rest cycle and proper posture is followed in hot sunny atmosphere. Proper training regarding the operating of serrated sickle is very important to reduce the squatting postures to avoid the Musculoskeletal problems associated.

\section{References}

Alka, S., Gautam, U.S., Rajesh, Singh., and Dinesh, P., 2014. Ergonomic study of farm women during wheat harvesting by improved sickle. African Journal of Agricultural Research. 9(18). 1 May 2014, pp. 1386-1390,. DOI: 10.5897/AJAR2013.7956.

Annonymous., 2001-02. All India Coordinated Research Project in Home Science: Annual Report, ICAR, New Delhi, India.

Bureau of Indian Standards., 1967. IS 4358:1967. Specification for sickles. ManakBhavan, New Delhi: BIS.

Borah, r., and kalita, M., 2002. Extent of participation and postures adopted in performance of farm activity by women in Assam Rural India. Journal of Ergonomics, 65(1) : 7-10.

Chauhan, MK., Saha, DN., 1999. Acceptable limits of physiological workload for physically active Indian women. Advance Training Course in Ergonomics, SNDT Women's University, Mumbai.

Corlett, E.N., AND Bishop, R,P.,1976. A Technique for assessing posture discomfort. Ergonomics, 11(1): 7-16.

Dilbaghi, M., Gandhi, S., Bimla, 2008. Ergonomic evaluation of improved sickles in wheat harvesting. J. Agric. Eng. New Delhi 1:7-11.

Doğan, M., 2004. Determination of Optimum Weed Control Timing in Maize (Zea mays L.), volume 28(5), Turkish Journal of Agriculture and Forestry January 2004/01/01

Gite, LP., Agarwal, N., 2000. Ergonomical comparison of local and improved sickles for wheat harvesting by women workers. Agric. Eng. Today 24(3):7-12.

Jyotsna, K. R., Singh, K., and Mehta, M. 2005. Ergonomic evaluation of the rural women while performing wheat harvesting activity. J. Hum. Ecol., 18(4), pp. 309-311.

Varghese, MA., Saha, PN., Atreya, N., 1994. A rapid appraisal of occupational workload from modified scale of perceived exertion. Ergonomics 37(3):485-

491.http://dx.doi.org/10.1080/00140139 408963665 PMid:8143693

Limbore., Nilesh., 2015.An analytical study of Indian agriculture crop production and export with reference to wheat $\mathrm{Vol}$ 4 Issue 6 March 2015

Vyavahare, R. T., Kallurkar S. T., 2012.Anthropometric and strength data of Indianagriculturalworkers for equipment design: a review, Agric EngInt: CIGR Journal, Vol. 14, No.4, 102-114, 2012

Kyle, Dooley., 2012.Ergonomics and the Development of Agricultural Vehicles, Agricultural Equipment Technology Conference. 


\section{How to cite this article:}

Anusha, M. and Mehta, A. K. 2021. Drudgery Reduction through Ergonomic Evaluation of Women Farm Workers using Local Sickle and Serrated Sickle During Harvesting in Wheat Crop of Udaipur District. Int.J.Curr.Microbiol.App.Sci. 10(01): 1075-1084.

doi: https://doi.org/10.20546/ijcmas.2021.1001.130 